Revista de BIOLOGía TROPICAL

\title{
Changes in body size spectra of benthic caridean shrimps (Decapoda: Caridea) and snails (Gastropoda) as response to seasonal variability
}

\author{
Ernesto I. Badano ${ }^{1 *}$, Fabio A. Labra ${ }^{2}$, Cecilia G. Martínez-Pérez ${ }^{3}$ \& Carlos H. Vergara ${ }^{3}$
}

1. División de Ciencias Ambientales, Instituto Potosino de Investigación Científica y Tecnológica. C. P. 78216, Camino a la Presa San José 2055, Colonia Lomas 4ta Sección, San Luis Potosí, México; ernesto.badano@ipicyt.edu.mx

2. Centro de Investigación en Ciencias Ambientales, Facultad de Ciencias, Universidad Santo Tomás. Ejército 146, Santiago, Chile; flabra@santotomas.cl

3. Departamento de Ciencias Químico-Biológicas, Escuela de Ciencias, Universidad de las Américas Puebla. C. P. 72820, Cholula, Puebla, México; carlosh.vergara@udlap.mx, cecilia.martinezperez@gmail.com

* Correspondence

Received 09-III-2015. C Corrected 05-IX-2015. Accepted 09-X-2015.

\begin{abstract}
Ecologists have been largely interested in the description and understanding of the power scaling relationships between body size and abundance of organisms. Many studies have focused on estimating the exponents of these functions across taxonomic groups and spatial scales, to draw inferences about the processes underlying this pattern. The exponents of these functions usually approximate $-3 / 4$ at geographical scales, but they deviate from this value when smaller spatial extensions are considered. This has led to propose that body size-abundance relationships at small spatial scales may reflect the impact of environmental changes. This study tests this hypothesis by examining body size spectra of benthic shrimps (Decapoda: Caridea) and snails (Gastropoda) in the Tamiahua lagoon, a brackish body water located in the Eastern coast of Mexico. We measured water quality parameters (dissolved oxygen, salinity, $\mathrm{pH}$, water temperature, sediment organic matter and chemical oxygen demand) and sampled benthic macrofauna during three different climatic conditions of the year (cold, dry and rainy season). Given the small size of most individuals in the benthic macrofaunal samples, we used body volume, instead of weight, to estimate their body size. Body size-abundance relationships of both taxonomic groups were described by tabulating data from each season into base-2 logarithmic body size bins. In both taxonomic groups, observed frequencies per body size class in each season were standardized to yield densities (i.e., individuals $/ \mathrm{m}^{3}$ ). Nonlinear regression analyses were separately performed for each taxonomic group at each season to assess whether body size spectra followed power scaling functions. Additionally, for each taxonomic group, multiple regression analyses were used to determine whether these relationships varied among seasons. Our results indicated that, while body size-abundance relationships in both taxonomic groups followed power functions, the parameters defining the shape of these relationships varied among seasons. These variations in the parameters of the body size-abundance relationships seems to be related to changes in the abundance of individuals within the different body size classes, which seems to follow the seasonal changes that occur in the environmental conditions of the lagoon. Thus, we propose that these body size-abundance relationships are influenced by the frequency and intensity of environmental changes affecting this ecosystem. Rev. Biol. Trop. 64 (1): 33-44. Epub 2016 March 01.
\end{abstract}

Key words: allometry, energetic equivalence, Mexico, non-equilibrium, power functions, seasonal changes.

Body size is the most fundamental property of living organisms because it relates with a number of life history traits including metabolism, abundance, lifespan, home range, reproduction and growth (Calder, 2000; Hildrew,
Raffaelli, \& Edmonds-Brown, 2007; MacNab, 1990; Peters, 1986; White, Ernest, Kerkhoff, \& Enquist, 2007). Ecologists have largely studied this phenomenon from an allometric perspective to determine how body size scaling explains 
variations in physiological and behavioral traits of species (Labra, Marquet, \& Bozinovic, 2007; Savage et al., 2004; White et al., 2007). Most these allometric relationships have been described through power functions, where the traits of interest $(y)$ relate to body size $(B S)$ as: $y=\alpha B S^{\beta}$. In these functions, $\alpha$ is the normalization constant and $\beta$ is the scaling exponent (Peters, 1986; Brown, Gillooly, Allen, Savage, \& West, 2004; Marquet et al., 2005; Labra et al., 2007). Given that scaling exponents typically take values that are multiples of $1 / 4$ (e.g., 1/4, 3/4, 3/8), some ecologists suggested that this an ecological law and it was called the quarter-power scaling rule (Brown, West, \& Enquist, 2000; Savage et al., 2004; West, Brown, \& Enquist, 2000).

The most widely studied of these allometric relationships is that between body size and the abundance of individuals $(D)$, often measured as density (Basset, Sangiorgio, \& Pinna, 2004; Marquet, Navarrete, \& Castilla, 1990; Nee, Read, \& Harvey, 1991; White et al., 2007). For most taxonomic groups of animals, the scaling exponents of these relationships usually approximates to $-3 / 4$ and, hence, $D=\alpha$ $B S^{-3 / 4}$ (Brown et al., 2000; Cyr, 2000; Peters, 1986). This has led to propose the energetic equivalence rule, which states that the total use of energy by populations is independent of the body size of their individuals (Nee et al., 1991). This energetic equivalence rule assumes that species abundances in natural communities are constrained by the total amount of energy, and resources that are available to individual organisms, and scaling exponents close to $-3 / 4$, are expected when the energetic balance of the ecosystems is at equilibrium (Marquet et al., $1990,2005)$. On the other hand, the normalization constant summarizes the effects of resource supply rates, space availability, and other sources of variability affecting body size and species densities within ecosystems (Brown et al., 2004; Marquet et al., 2005).

The scaling relationship described above performs well at large geographical scales, such as continents, but its shape is still being matter of discussion on smaller spatial scales
(White et al., 2007). Aquatic ecologists, for example, have usually analyzed the frequency distribution of body sizes regardless the species to which organisms belong, or body size spectra, and studies conducted in small water bodies have reported scaling exponents that largely deviate from the expected value of -3/4 (Boix, Sala, Quintana, \& Moreno-Amich, 2004; Schmid, Tokeshi, \& Schmid-Araya, 2000, 2002). Indeed, recent studies on benthic macroinvertebrates from Mediterranean lagoons have shown that local body size-abundance relationships can be polygonal in shape, with the highest population density per size class increasing with average individual body size of $0.25 \mathrm{mg}$ and decreasing beyond this threshold (Barbone, Rosati, Pinna, \& Basset, 2007; Basset et al., 2008). These differences between observed and expected body size-abundance relationships have been attributed to external disturbances that affect aquatic ecosystems (e.g., seasonal changes in water discharge regimens, anthropogenic disturbances or variations in resource supply rates from terrestrial ecosystems) instead of energetic or resources constraints (Barbone et al., 2007; Basset et al., 2008; Schmid et al., 2000). Therefore, the scaling relationships expected on geographical scales may not be attained at small spatial scales when local species assemblages are affected by external disturbances or cyclical environmental changes. Indeed, at small spatial scales, scaling exponents of body size spectra may vary idiosyncratically across time because environmental variability may prevent the community from reaching energetic equilibrium states.

To test these hypotheses we focused in a coastal brackish lagoon of Mexico that is recurrently affected by seasonal changes in water quality conditions. In this ecosystem, we assessed the body size spectra of two groups of benthic macroinvertebrates including infaunal and epifaunal caridean shrimps (Crustacea) and snails (Gastropoda). Body size spectra of these two groups were expected to fit power law functions, but we also expected changes in the parameters describing these 
relationships ( $\alpha$ and $\beta$ ) after changes in water quality conditions.

\section{MATERIALS AND METHODS}

Study site: This study was conducted in the Tamiahua lagoon located in the North of the State of Veracruz, Mexico $\left(21^{\circ} 15^{\prime} \mathrm{N}\right.$ - 97 $\left.19^{\prime} \mathrm{W}\right)$. It covers 88000 ha and has an average depth of $2 \mathrm{~m}$ (Contreras, 1988). Four small rivers with irregular flow (Tampache, Carbajal, Cucharas and Tancochín) discharge their waters in this lagoon and a sand barrier separates it from the Gulf of Mexico (Cruz, 1968). The lagoon is connected to the Gulf of Mexico through a $15 \mathrm{~m}$ wide natural channel located in its Southern section, but its Northern section has been artificially connected to the sea through a $20 \mathrm{~m}$ wide channel. Local climate is tropical-type, but there are three clearly distinct seasons throughout the year. The coldest period occurs between October and February, when air temperature may fall below $15{ }^{\circ} \mathrm{C}$. This cold season is characterized by frequent invasions of polar air masses from the North, which cause violent hurricane systems and some precipitation events (less than $400 \mathrm{~mm}$ across this season) (Contreras, 1988). It is followed by the dry season, between March and May, with air temperatures between $22{ }^{\circ} \mathrm{C}$ and $30{ }^{\circ} \mathrm{C}$ and scarce precipitation events (less than $100 \mathrm{~mm}$ across this season) (Contreras, 1988). Finally, the rainy season occurs between June and September, concurring with the warmest period of the year. Air temperatures in this season surpass $40{ }^{\circ} \mathrm{C}$ and it concentrates up to 85 $\%$ of annual rainfalls (above $1000 \mathrm{~mm}$ across the season) (Contreras, 1988). During the rainy season, there are strong increases in the flows of neighboring rivers, which increase the load of sediments and organic matter in the lagoon (Cruz, 1968).

Environmental variables: Water quality conditions in the lagoon were assessed in eight fixed sampling stations located 3-5 $\mathrm{km}$ away each other on the Western coast of the lagoon (Table 1). During 2008, dissolved oxygen, salinity, $\mathrm{pH}$, and water temperature were measured at each sampling station at the middle of the three seasons (January $11^{\text {th }}$, April $18^{\text {th }}$ and July $25^{\text {th }}$ ). For this we used a multiparameter probe $(6600 \mathrm{~V} 2$, YSI Incorporated, USA) that was immersed $20 \mathrm{~cm}$ deep in the water column. A one-liter core sample was also taken from the bottom of the lagoon at each sampling station. These samples were placed at $5{ }^{\circ} \mathrm{C}$ immediately after collection to reduce metabolic activity and taken to the Laboratory of Physicochemical Processes of University of the Americas Puebla (Mexico) to determine the amount of organic matter in sediments and the chemical oxygen demand (COD). These analyses were conducted within three days after collecting the sediment samples. Repeated measures ANOVA were used to compare these variables among seasons. In these analyses, sampling stations were considered as replicates and seasons were the repeated measures (Zar, 2010). When significant differences were detected, the Tukey's post hoc test was used to assess differences between seasons.

\section{Macroinvertebrate sampling and body} size measures: Benthic macroinvertebrates were sampled in the stations mentioned above (Table 1) on the same dates in which the environmental variables were measured (January $11^{\text {th }}$, April $18^{\text {th }}$ and July $25^{\text {th }}$ ). At each station we drew a $30 \mathrm{~m}$ line-transect located $20 \mathrm{~m}$

TABLE 1

Sampling sites in the Tamiahua Lagoon

\begin{tabular}{|c|c|c|}
\hline Sampling site & Longitude & Latitude \\
\hline Site 1 & $21^{\circ} 21^{\prime} 39.41^{\prime \prime} \mathrm{N}$ & $97^{\circ} 29^{\prime} 16.13^{\prime \prime} \mathrm{O}$ \\
\hline Site 2 & $21^{\circ} 24^{\prime} 41.35^{\prime \prime} \mathrm{N}$ & $97^{\circ} 29^{\prime} 47.92^{\prime \prime} \mathrm{O}$ \\
\hline Site 3 & $21^{\circ} 28^{\prime} 03.29^{\prime \prime} \mathrm{N}$ & $97^{\circ} 29^{\prime} 36.84^{\prime \prime} \mathrm{O}$ \\
\hline Site 4 & $21^{\circ} 28^{\prime} 12.72^{\prime \prime} \mathrm{N}$ & $97^{\circ} 33^{\prime} 30.45^{\prime \prime} \mathrm{O}$ \\
\hline Site 5 & $21^{\circ} 30^{\prime} 35.26^{\prime \prime} \mathrm{N}$ & $97^{\circ} 35^{\prime} 09.76^{\prime \prime} \mathrm{O}$ \\
\hline Site 6 & $21^{\circ} 32^{\prime} 53.56^{\prime \prime} \mathrm{N}$ & $97^{\circ} 36^{\prime} 58.34^{\prime \prime} \mathrm{O}$ \\
\hline Site 7 & $21^{\circ} 36^{\prime} 01.31^{\prime \prime} \mathrm{N}$ & $97^{\circ} 38^{\prime} 03.90^{\prime \prime} \mathrm{O}$ \\
\hline Site 8 & $21^{\circ} 38^{\prime} 36.49^{\prime \prime} \mathrm{N}$ & $97^{\circ} 39^{\prime} 50.09^{\prime \prime} \mathrm{O}$ \\
\hline
\end{tabular}

Coordinates of the eight sites where water quality conditions were assessed and benthic macroinvertebrates were sampled at each season. 
away from the coast line. On this transect, we collected one-liter sediment samples every $10 \mathrm{~m}$ with a cylindrical hand corer $(20 \mathrm{~cm}$ diameter x $32 \mathrm{~cm}$ depth). This resulted in four samples per transect, which were pooled to obtain a single composite sediment sample at each sampling station. Composite samples were sieved through a $0.5 \mathrm{~mm}$ mesh to remove sediments and macroinvertebrates retained in the sieve were preserved in formalin solution (7\%) buffered with sodium borate $(28 \mathrm{~g} / \mathrm{L})$ (Marini, Pinna, Basset \& Mancinelli, 2013; Sangiorgio et. al, 2014). Macroinvertebrates from each sample were separately stored and taken to the Laboratory of Entomology of the University of the Americas Puebla (Mexico), where they were washed with distilled water and preserved in ethanol solution (70 \%).

Because caridean shrimps and snails were the most abundant organisms in the samples, these two taxonomic groups were selected to perform the body size spectra analyses. These analyses considered all species of caridean shrimps and snails retained in the samples after the sieving (i.e., all individuals larger than 0.5 $\mathrm{mm})$. We were unable to identify collected specimens because detailed taxonomic descriptions of local fauna are still lacking. Nevertheless, previous studies reported that caridean shrimps of this lagoon are subsurface deposit feeders (algae grazers and scavengers) that belong to the families Palaemonidae and Hippolytidae (Álvarez, Villalobos, Rojas, \& Robles, 1999). Snails of the lagoon belong to the families Acteonidae, Acteocinidae, Cerithiidae, Nassariidae, Turriidae and Vitrinellidae, which are subsurface carnivores and occasional scavengers (Reguero \& García-Cuba, 1989; Reguero, García-Cuba, \& Zúñiga, 1991).

Collected specimens were extremely small to be weighed and, for this reason, we used body volume instead of body mass as a surrogate of body size (Calder, 2000; McClain, 2004; Siemann, Tilman, \& Haarstad, 1996). For this, each specimen was placed under a stereoscopic dissection microscope with scaled lens (STEMI SV6, Zeiss, Germany). In the case of shrimps we measured their length $(l)$, from the rostrum to the last segment of the body, and width (w); antenna, flagellum, pereopods, pleopod and telson were not included in these measures because these structures are highly variable among species. Thus, the body volume $\left(V_{\text {shrimp }}\right)$ of shrimps was estimated by following the mathematical formula of a cylinder: $V_{\text {shrimp }}$ $=l w^{2}$. Because the body of snails is almost conical, to estimate their volume we measured the length of each shell $(h)$ and the width of its base $(b)$, and the body volume $\left(V_{\text {snail }}\right)$ was estimated as: $V_{\text {snail }}=\left[\pi(1 / 2 b)^{2} h\right] / 3$. In both cases, decaying organisms and empty snail shells were not measured to ensure that only individuals that were alive at the time of sampling were included in the analyses described below.

Body size spectra: Body size spectra describe the frequency distribution of individuals according to body size classes, irrespective of the species they belong to (Sheldon, Prakash, \& Sutcliffe, 1972; White et al., 2007). This method is commonly employed to assess body size abundance relationships when sampled individuals are too numerous and the species are hard to recognize, as occur in benthic macroinvertebrate assemblages (Dinmore \& Jennings, 2004; Drgas, Radziejewska, \& Warzocha 1998; Kaariainen \& Bett, 2006; Mancinelli, Pinna, \& Basset, 2008; Mouillot et al., 2006).

The main drawback of this method is defining objective criteria for establishing the width of the body size classes to which individuals are assigned. In most studies, the researchers arbitrarily define these body size classes, but this procedure can bias the shape of these relationships according to the width and number of body size classes that are established (Mancinelli et al., 2008). To avoid such arbitrariness we used the logarithmic binning method suggested by White, Enquist, \& Green (2008). This method consists in constructing as many body size classes as necessary to cover the entire range of body sizes, but the width of the size classes increases by following a logarithmic scale. Once all these body size classes are defined, the individuals are assigned to the size class they belong to and counted. In our case, the width of the size classes was established by 
using a $\log _{2}$-scale, as recommended by White et al. (2008) for assessing body size spectra in small organisms.

Given that the number of individuals within each body size class was obtained from $32 \mathrm{~L}$ of sediment at each season (four $1 \mathrm{~L}$ samples $\mathrm{x}$ eight sampling stations), the density of individuals at each size class was standardized to a volume of $1 \mathrm{~m}^{3}$ for both taxonomic groups (i.e., individuals $/ \mathrm{m}^{3}$ ). After that, nonlinear regression analyses were separately performed for each taxonomic group at each season to assess whether body size spectra fitted to power functions and hence estimate the normalization constants $(\alpha)$ and scaling exponents $(\beta)$ of these relationships. For these analyses, we used nonlinear regression models with the following function: $A=\alpha V^{\beta}$, where $A$ is density of individuals and $V$ is the median value of the different body volume classes (Peters, 1986).

The analyses described above allowed us to determine the values of $\alpha$ and $\beta$ for the body size spectra of shrimps and snails at each season, but using nonlinear methods to statistically compare these values among seasons is extremely complex. For this reason, these relationships were linearized by applying the $\log _{2}$ transformation to the median value of body size classes and their respective abundances of individuals. In this way, the values of $\alpha$ and $\beta$ were compared among seasons by using multiple linear regression analysis with categorical variables (Kutner, Nachtsheim, Christopher, Neter, \& Li, 2005). Therefore, the log-transformed density of individuals within each size class was the continuous response variable, the log-transformed median value of the different size classes was the continuous predictive variable, and the sampling seasons (cold, dry and rainy season) were the three levels of the categorical predictive variable. Regression models used in these analyses also included all possible interaction terms between predictive variables, allowing us to assess differences among estimated parameters (Kutner et al., 2005). Differences in intercepts $\left(\log _{2} \alpha\right)$ and slopes $(\beta)$ of regression functions obtained for the different seasons were assessed with t-tests (Kutner et al., 2005).

\section{RESULTS}

Physical-chemical variables: All physical-chemical variables measured in the water column and sediments differed among seasons (repeated measures ANOVA $\mathrm{p}<0.01$ in all cases). Post hoc comparisons indicated that dissolved oxygen, salinity and COD significantly differed among all three seasons. The highest average value of dissolved oxygen was found in the dry season, while its lowest value was recorded in the rainy season (Fig. 1A). Both salinity (Fig. 1B) and COD (Fig. 1C) showed their higher values in the dry season, while their lower values were observed in the cold season. Water temperature (Fig. 1D) showed similar values in the dry and rainy seasons but, in both cases, these values were higher than in the cold season. Organic matter (Fig. 1E) and $\mathrm{pH}$ (Fig. 1F) were higher in the rainy season than in the other two seasons.

Body size spectra: Densities of shrimps and snails significantly decreased with increasing body size in the three seasons. Simple nonlinear regression analyses (Table 2) indicated that these body size spectra are well described by power functions (Fig. 2). Nevertheless, normalization constants and scaling exponents of these relationships changed across seasons in both taxonomic groups. For caridean shrimps, the power function with the highest normalization constant $(\alpha)$ and the lowest scaling exponent $(\beta)$ was obtained in the dry season (Fig. 2 ). These values of $\alpha$ and $\beta$ coincided with the period of the year in which higher abundances of individuals smaller than $1 \mathrm{~mm}^{3}$ in body size were recorded (up to $40875 \mathrm{ind} / \mathrm{m}^{3}$ ). The rainy and cold seasons showed lower densities of shrimps smaller than $1 \mathrm{~mm}^{3}$ (below $20000 \mathrm{ind} /$ $\mathrm{m}^{3}$ ), which lead to lower values of $\alpha$ (Fig. 2). Conversely, the values of $\beta$ in these two seasons were higher than those found in the dry season (Fig. 2). For snails, the highest value of $\alpha$ and the lowest value of $\beta$ were obtained 

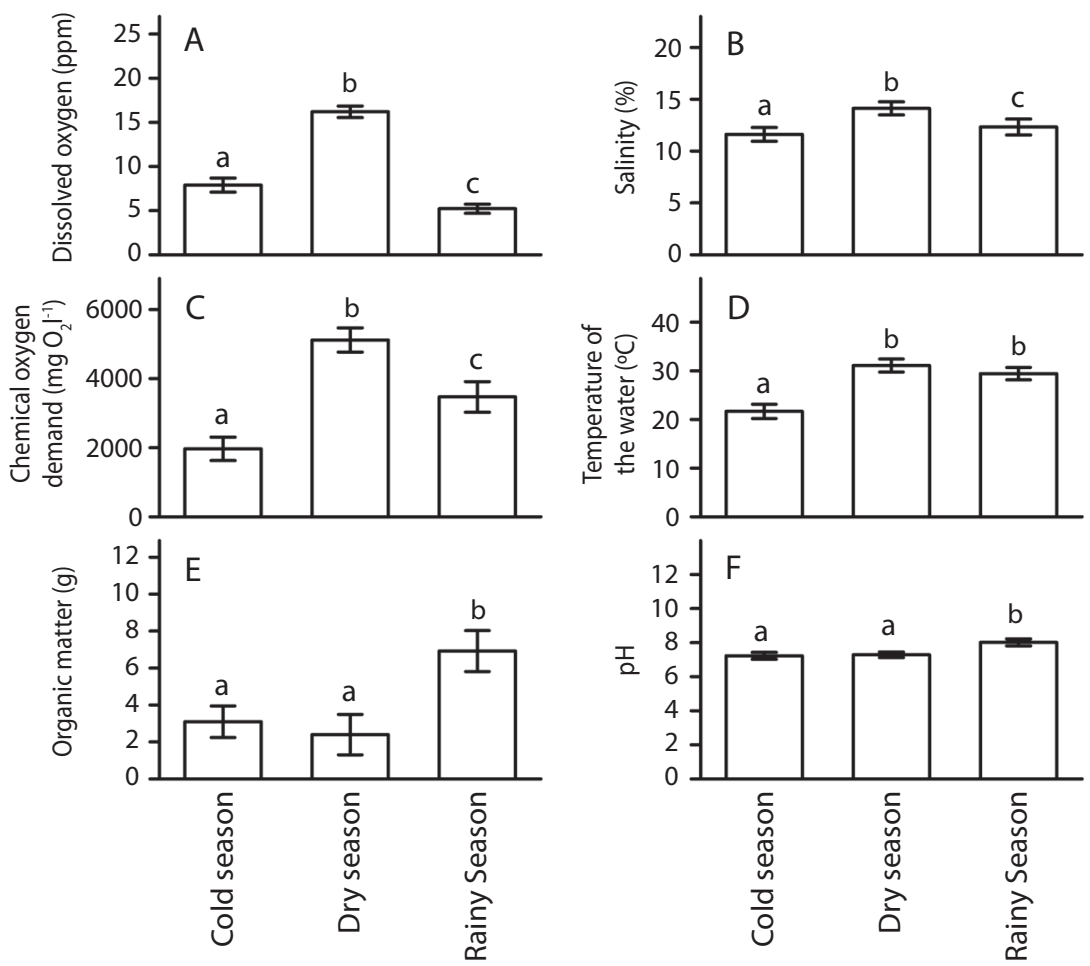

Fig. 1. Physicochemical variables (averages \pm 2 S.E.) measured at the cold, dry and rainy seasons in the Tamiahua Lagoon, Mexico, including dissolved oxygen (A), salinity (B), chemical oxygen demand (C), temperature of water (D), organic matter in sediments (E) and $\mathrm{pH}(\mathrm{F})$. Significant differences between seasons are indicated with different letters (Tukey test critical $\alpha=0.05)$.

in the rainy season (Fig. 2). This coincided with the period of the year in which the largest density of snails with body sizes smaller than $1 \mathrm{~mm}^{3}$ was recorded (up to 15906 ind $/ \mathrm{m}^{3}$ ). In both the cold and dry seasons, densities of snails smaller than $1 \mathrm{~mm}^{3}$ were below 7000 ind $/ \mathrm{m}^{3}$ and body size spectra then showed lower values of $\alpha$, but higher values of $\beta$, than those estimated in the rainy season (Fig. 2).

Multiple linear regression analyses conducted with $\log _{2}$-transformed data indicated that the values of $\alpha$ and $\beta$ differed among seasons for both shrimps $\left(\mathrm{F}_{(5,14)}=54.901, \mathrm{p}<\right.$ $\left.0.001, \mathrm{R}^{2}=0.951\right)$ and snails $\left(\mathrm{F}_{(5,20)}=90.446\right.$, $\mathrm{p}<0.001, \mathrm{R}^{2}=0.967$ ). Caridean shrimps (Fig. $3 \mathrm{~A})$ showed significantly higher values of $\alpha$, but lower values of $\beta$, in the dry season than in the other two seasons (t-test $p<0.001$ in both cases). For caridean shrimps, neither differences in $\alpha\left(\mathrm{t}_{(14,1)}=0.780, \mathrm{p}=0.448\right)$ nor $\beta\left(\mathrm{t}_{(14,1)}\right.$ $=0.134, \mathrm{p}=0.895)$ were found between the rainy and cold seasons. Snails (Fig. 3B) displayed significantly higher values of $\alpha$ and $\beta$ in the rainy season (t-test $\mathrm{p}<0.001$ in both cases), but neither $\alpha\left(\mathrm{t}_{(14,1)}=1.620, \mathrm{p}=0.120\right)$ nor $\beta$ $\left(\mathrm{t}_{(14.1)}=1.087, \mathrm{p}=0.295\right)$ differed between the cold and the dry seasons.

\section{DISCUSSION}

Overall, our results suggest that body size spectra of both taxonomic groups analyzed in this study can be described through power functions. Nevertheless, these results also indicated that the normalization constants $(\alpha)$ and the scaling exponents $(\beta)$ describing these 


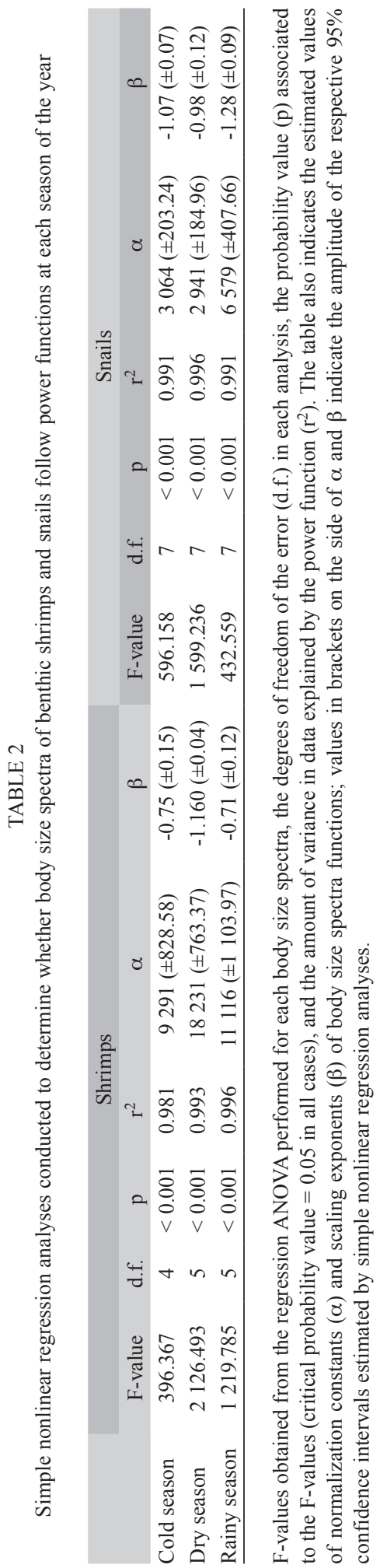

relationships varied across seasons of the year. Indeed, the scaling exponents rarely reached the widely expected value of $-3 / 4$ (Cyr, 2000). These deviations from the scaling exponent that is expected under energetic balance conditions suggest that the loads of matter and energy in this water body may be changing across seasons, which in turn impact on the local species assemblages and force them to depart from their energetic equivalence equilibrium states. On this issue, it is important to note that the body size spectra of both shrimps and snails attained greater values of $\alpha$ and lower values of $\beta$ in those seasons when the abundance of individuals in the smaller body size classes increased (dry season for shrimps and rainy season for snails). This suggests that body size spectra of these organisms may be partially regulated by reproductive pulses that occur with changing environmental signals.

Previous studies have shown that reproduction of shrimps in brackish waters is triggered by increases in dissolved oxygen (Attrill \& Power, 2000; Viegas, Martinho, Neto, \& Pardal, 2007). In our case these conditions occurred in the dry season, coinciding with an increased abundance of shrimps smaller than $1 \mathrm{~mm}^{3}$ in body volume. This suggests that the recruitment of caridean shrimps occurs in this season, when these organisms might take advantage of the increased inputs of oxygen to reach the energetic levels required to produce offspring. As a consequence of this increased external input of available energy, the value of $\beta$ dropped below $-8 / 5$ (-1.16) in the body size spectrum obtained in dry season.

Reproductive events of snails in brackish wetlands, on the other hand, usually concur with greater loads of organic matter (Antonio et al., 2010; Naranjo-García, 2003; NaranjoGarcía \& Meza-Meneses, 2000). In our study system this occurred during the rainy season, when the rivers that discharge their waters in the lagoon increase their flows and, consequently, the inputs of organic matter that comes from the surrounding terrestrial ecosystems. In this season, the value $\beta$ in the body size spectrum was below $-5 / 4(-1.28)$, which could also 

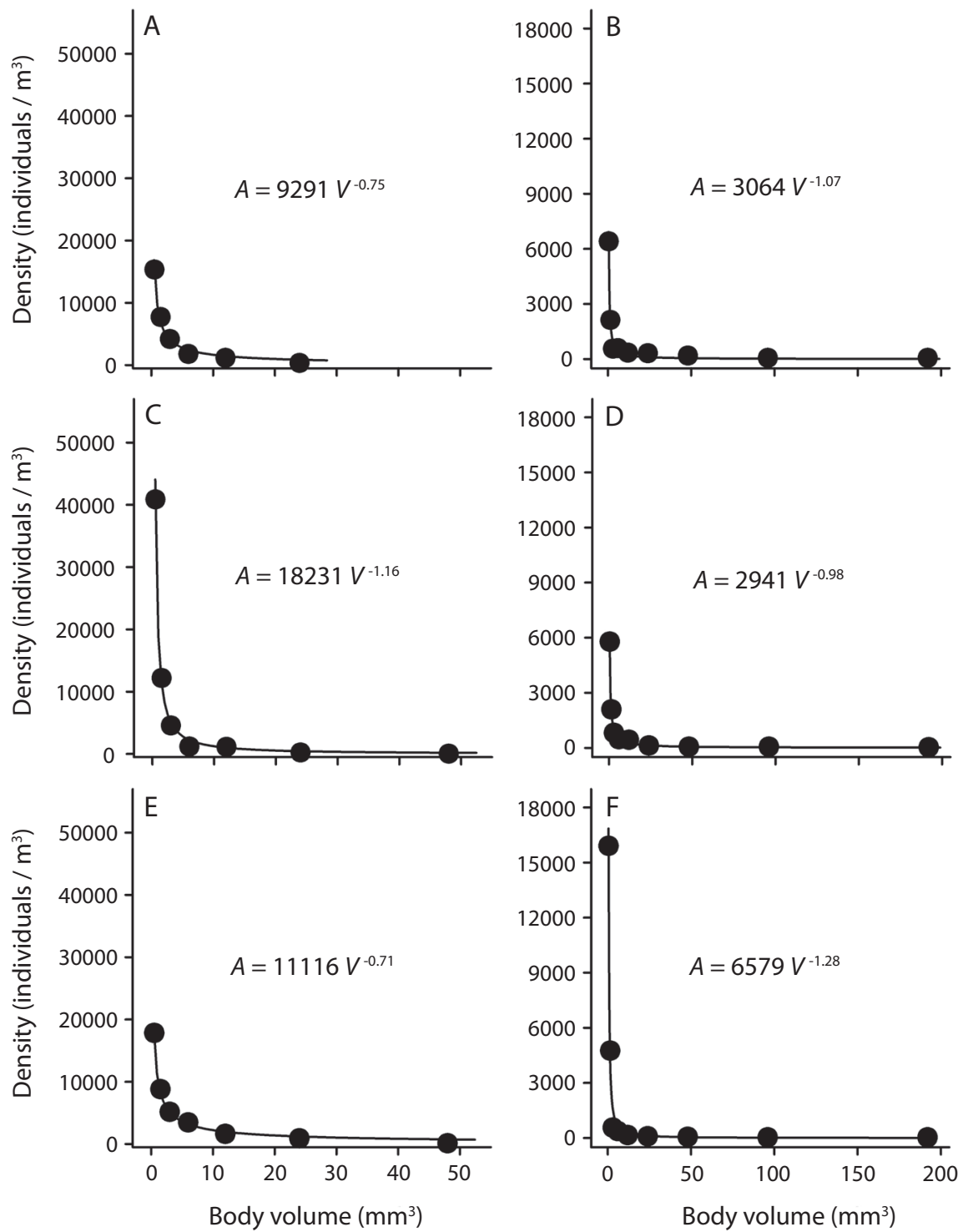

Fig. 2. Body size spectra of shrimps (left column) and snails (right column) estimated at the cold (A-B), dry (C-D) and rainy (E-F) seasons. The power functions describing these relationships between the density of individuals and the body volume are provided in the respective panel.

be due to the increased density of small newborn individuals that occurred because a higher availability of food resources.

For both taxonomic groups, the comparisons of body size spectra among seasons also indicated that the values of $\alpha$ declined, while values of $\beta$ rose, as the number of individuals in the smaller body size classes decreased.
For shrimps this occurred during the cold and rainy seasons, while snails showed decreases in the abundance of smaller individuals during the cold and dry seasons. Such decreases in the abundance of smaller individuals may be due to increased predation intensity of newborn individuals by fish and other organisms, or because environmental conditions after 

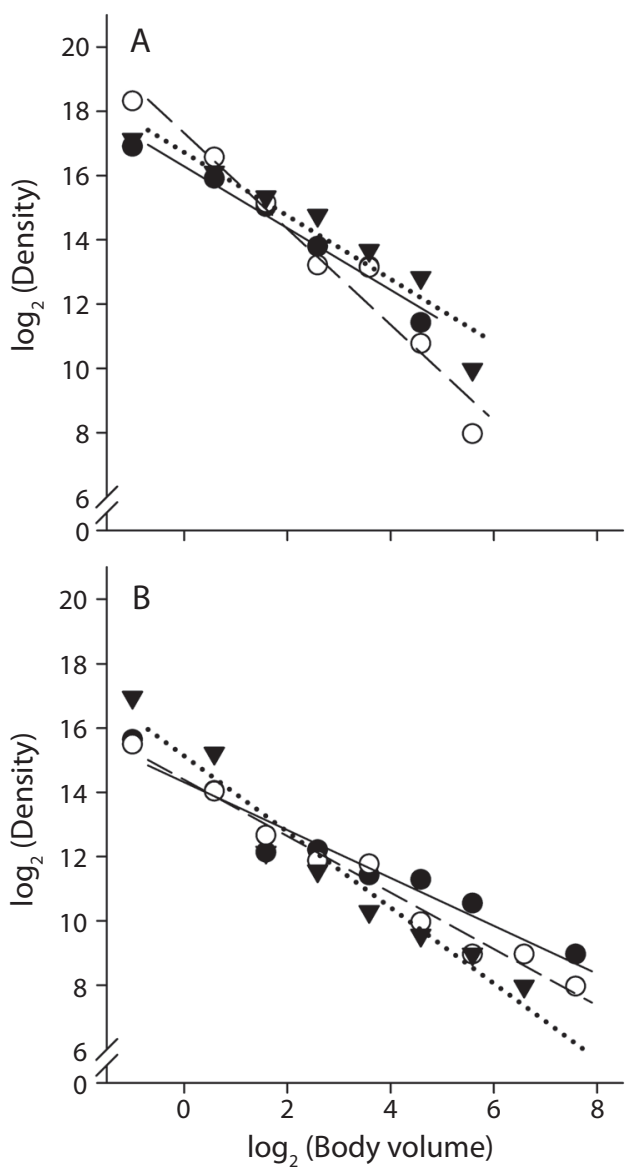

Fig. 3. Linearized body size spectra of shrimps (A) and snails (B) resulting from the multiple linear regression analyses conducted to determine differences in normalization constants and scaling exponents among the cold (solid circles-solid line), dry (empty circles-dashed line) and rainy (solid triangles-dotted line) seasons.

breeding periods are adverse for the survival and development of juvenile stages (Boix et al., 2004; Gosselin \& Qian, 1997; Kneib, 1987; Pechenik, 1999; Sola, 1996). Irrespective of the factors that caused these decreases in the abundance of smaller individuals, this may relax the contribution of smaller body size classes to the shape of body size spectra, leading to lower values of $\alpha$ and higher values of $\beta$ as observed in this study.

Interestingly, the values of $\beta$ in the body size spectra of shrimps were close to the expected value of $-3 / 4$ after the dry season $(\beta=-0.71$ in the rainy season and $\beta=-0.75$ in the cold season). This suggests that external climatic forces (e.g., changes in environmental conditions) or internal biotic pressures (e.g., increased predation) may pull down the excess of energy within this species assemblage after the reproductive season, hence approaching it to energetic equilibrium states. Scaling exponents of snails, on the other hand, were never close to this expected value of $-3 / 4$. Indeed, the body size spectra this group of organisms showed steeper slopes which approximated to $-4 / 4$ during both the dry (-0.98) and cold seasons (-1.07). These deviations from the expected $-3 / 4$ scaling exponent clearly suggest that this species assemblage is constantly departed from their energetic equilibrium state. However, elucidating what factors caused these deviations in the dry and cold seasons require detailed studies about the responses these species to different environmental factors, which are still lacking for most snails from the Gulf of Mexico.

As final remark it is important to highlight that, although scaling exponents of $-3 / 4$ seem to be the rule for body size-abundance relationships at geographical scales (Peters, 1986; Brown et al., 2000; Cyr, 2000), our results suggest that these values may vary idiosyncratically at local smaller scales. Indeed, our study suggests that species assemblages inhabiting ecosystems subjected to cyclical changes in environmental conditions would rarely reach their energy balance because they would not necessarily respond to local energetic constraints. Instead, since the inputs of matter and energy in these ecosystems seem to be controlled by external factors (e.g., seasonality), these species assemblages would be constantly restructured after these changes occur.

\section{ACKNOWLEDGMENTS}

The authors thank the financial support provided by Fondo Mixto de Fomento a la Investigación Científica y Tecnológica CONACYT-Gobierno del Estado de Veracruz, VER-2006-01-37557. 


\section{RESUMEN}

Los ecólogos han estado muy interesados en describir y comprender las relaciones escalares de potencia entre el tamaño corporal y la abundancia de los organismos. Muchos estudios se han centrado en la estimación de los exponentes de estas funciones a través de grupos taxonómicos y escalas espaciales, para sacar conclusiones acerca de los procesos que subyacen a este patrón. Los exponentes de estas funciones generalmente se aproximan $-3 / 4$ a escalas geográficas, pero se apartan de este valor cuando se consideran extensiones espaciales más pequeñas. Esto ha llevado a proponer que las relaciones tamaño corporal-abundancia en pequeñas escalas espaciales puede reflejar el impacto de cambios ambientales. Este estudio pone a prueba esta hipótesis mediante el examen de los espectros de tamaño corporal de camarones bentónicos (Decapoda: Caridea) y caracoles (Gastropoda) en la laguna de Tamiahua, un cuerpo de agua salobre situado en la costa oriental de México. Medimos parámetros de calidad del agua (oxígeno disuelto, salinidad, $\mathrm{pH}$, temperatura del agua, materia orgánica en los sedimentos y demanda química de oxígeno) y muestreamos la macrofauna bentónica en tres momentos del año que difieren en sus condiciones climáticas (estaciones fría, seca y de lluvias). Dado el pequeño tamaño de la mayoría de los individuos en las muestras de macrofauna bentónica, se utilizó el volumen del cuerpo, en lugar de peso, para estimar su tamaño corporal. Las relaciones tamaño corporalabundancia de ambos grupos taxonómicos fueron descritas ordenando los datos de cada estación en clases de tamaño corporal cuya amplitud estaba establecida por una escala logarítmica de base 2. En ambos grupos taxonómicos, las frecuencias observadas por clase de tamaño corporal en cada estación se estandarizaron a densidades de captura (es decir, individuos $/ \mathrm{m}^{3}$ ). Análisis de regresión no-lineal se realizaron separadamente para cada grupo taxonómico en cada estación del año para evaluar si los espectros de tamaño corporal seguían funciones escalares de potencia. Además, para cada grupo taxonómico, se utilizaron análisis de regresión múltiple para determinar si estas relaciones variaban entre estaciones. Nuestros resultados indicaron que, mientras las relaciones tamaño corporal-abundancia en ambos grupos taxonómicos siguieron funciones potenciales, los parámetros que definen la forma de estas relaciones variaron entre estaciones. Estas variaciones en los parámetros de las relaciones tamaño corporal-abundancia parecen estar relacionadas con cambios en la abundancia de los individuos dentro de las diferentes clases de tamaño corporal, que parece seguir los cambios estacionales que se producen en las condiciones ambientales de la laguna. Por lo tanto, proponemos que estas relaciones tamaño corporalabundancia se ven influidas por la frecuencia e intensidad de los cambios ambientales que afectan este ecosistema.

Palabras clave: alometría, equivalencia energética, México, no-equilibrio, funciones de potencia, cambios estacionales.

\section{REFERENCES}

Álvarez, F., Villalobos, J. L., Rojas, Y., \& Robles, R. (1999). Listas y comentarios sobre los crustaceos decapodos de Veracruz, Mexico. Anales del Instituto de Biología UNAM, Serie Zoología, 70, 1-27.

Antonio, E. S., Kasai, A., Ueno, M., Kurikawa, Y., Tsuchiya, K., Toyohara, H., Ishihi, Y., Yokoyama, H., \& Yamashita, Y. (2010). Consumption of terrestrial organic matter by estuarine mollusks determined by analysis of their stable isotopes and cellulase activity. Estuarine, Coastal and Shelf Science, 86, 401-407.

Attrill, M. J., \& Power, M. (2000). Effects on invertebrate populations of drought-induced changes in estuarine water quality. Marine Ecology Progress Series, 203, 133-143.

Barbone, E., Rosati, I., Pinna, M., \& Basset, A. (2007). Taxonomic and dimensional structure of benthic macroinvertebrate guilds in the Margherita di Savoia Salt Pans (Italy). Transitional Waters Bulletin, 1, 21-31.

Basset, A., Sabetta, L., Sangiorgio, F., Pinna, M., Migoni, D., ... Beqiraj, S. (2008). Biodiversity conservation in Mediterranean and Black Sea lagoons: a traitoriented approach to benthic invertebrate guilds. Aquatic Conservation, Marine and Freshwater Ecosystems, 18, 4-15.

Basset, A., Sangiorgio, F., \& Pinna, M. (2004). Monitoring with benthic macroinvertebrates: advantages and disadvantages of body size descriptors. Aquatic Conservation, 14, S43-S58.

Boix, D., Sala, J., Quintana, X. D., \& Moreno-Amich, R. (2004). Succession of the animal community in a Mediterranean temporary pond. Journal of the North American Benthological Society, 23, 29-49.

Brown, J. H., Gillooly, F. J., Allen, A. P., Savage, V. M., \& West, G. B. (2004). Toward a metabolic theory of ecology. Ecology, 85, 1771-1789.

Brown, J. H., West, G. B., \& Enquist, B. J. (2000). Scaling in biology: patterns and processes, causes and consequences. In J. H. Brown, \& G. B. West (Eds.), Scaling in biology (pp. 1-24). New York: Oxford University Press.

Calder, W. A. (2000). Diversity and convergence: scaling for conservation. In J. H. Brown, \& G. B. West (Eds.), Scaling in biology (pp. 297-323). New York: Oxford University Press.

Contreras, F. (1988). Las lagunas costeras mexicanas. Mexico City: Secretaría de Pesca.

Cruz, R. (1968). Geología marina de la Laguna de Tamiahua, Veracruz, México. Boletín del Instituto de Geología UNAM, 88, 1-47.

Cyr, H. (2000). Individual use and the allometry of population density. In J. H. Brown, \& G. B. West (Eds.), 
Scaling in biology (pp. 267-296). New York: Oxford University Press.

Dinmore, T. A., \& Jennings, A. (2004). Predicting abundance-body mass relationships in benthic infaunal communities. Marine Ecology Progress Series, 276, 289-292.

Drgas, A., Radziejewska, T., \& Warzocha, J. (1998). Biomass size spectra of near-shore shallow-water benthic communities in the Gulf of Gdask (Southern Baltic Sea). Marine Ecology, 19, 209-228.

Gosselin, L., \& Qian, P. (1997). Juvenile mortality in benthic marine invertebrates. Marine Ecology Progress Series, 146, 265-282.

Hildrew, A. G., Raffaelli, D. G., \& Edmonds-Brown, R. (2007). Body size: the structure and function of aquatic ecosystems. New York: Cambridge University Press.

Kaariainen, J. I., \& Bett, B. J. (2006). Evidence for benthic body size miniaturization in the deep sea. Journal of the Marine Biological Association United Kingdom, 86, 1339-1345.

Kneib, R. T. (1987). Predation risk and use of intertidal habitats by young fishes and shrimp. Ecology, 68, 379-386.

Kutner, M. H., Nachtsheim, C., Christopher, J., Neter, J., \& Li, W. (2005). Applied linear models. New York: McGraw-Hill/Irwin.

Labra, F. A., Marquet, P. A., \& Bozinovic, F. (2007). Scaling metabolic rate fluctuations. Proceedings of the National Academy of Sciences USA, 104, 10900-10903.

MacNab, B. K. (1990). The physiological significance of body size. In J. Damuth, \& B. J. MacFadden (Eds.), Body Size in Mammalian Paleobiology: Estimation and Biological Implications (pp. 11-24). New York: Cambridge University Press.

Mancinelli, G., Pinna, M., \& Basset, A. (2008). Spatiotemporal variability of macrozoobenthos size structure of a coastal lagoon: the influence of spectrum resolution. Transitional Waters Bulletin, 2, 81-92.

Marini, G., Pinna, M., Basset, A., \& Mancinelli, G. (2013). Estimation of benthic macroinvertebrates taxonomic diversity: testing the role of sampling effort in a Mediterranean transitional water ecosystem. Transitional Waters Bulletin, 7, 28-40.

Marquet, P. A., Navarrete, S. A., \& Castilla, C. J. (1990). Scaling population density to body size in rocky intertidal communities. Science, 250, 1125-1127.

Marquet, P. A., Quiñones, R. A., Abades, S., Labra, F., Tognelli, M., Arim, M., \& Rivadeneira, M. (2005). Scaling and power-laws in ecological systems. Journal of Experimental Biology, 208, 1749-1769.
McClain, C. R. (2004). Connecting species richness, abundance and body size in deep-sea gastropods. Global Ecology and Biogeography, 13, 327-334.

Mouillot, D., Spatharis, S., Reizopoulou, S., Laugier, T., Sabetta, L., Basset, A., \& Chi, T. D. (2006). Alternatives to taxonomic-based approaches to assess changes in transitional water communities. Aquatic Conservation, 16, 469-482.

Naranjo-García, E. (2003). Moluscos continentales de México: dulceacuícolas. Revista de Biología Tropical, 51, 495-505.

Naranjo-García, E., \& Meza-Meneses, G. (2000). Moluscos. In G. S. de la Lanza-Espino, P. Hernández, \& J. Carvajal (Eds.), Organismos Indicadores de la Calidad del Agua y de la Contaminación (pp. 309-404). Mexico City: Plaza y Valdéz.

Nee, S., Read, A. F., \& Harvey, P. H. (1991). The relationship between abundance and body size in British birds. Nature, 351, 312-313.

Pechenik, J. A. (1999). On the advantages and disadvantages of larval stages in benthic marine invertebrate life cycles. Marine Ecology Progress Series, 177, 269-297.

Peters, R. H. (1986). The ecological implications of body size. New York: Cambridge University Press.

Reguero, M., \& García-Cuba, A. (1989). Moluscos de la Laguna de Alvarado, Veracruz: sistemática y ecología. Anales del Instituto de Ciencias del Mar y Limnología UNAM, 16, 279-306.

Reguero, M., García-Cuba, A., \& Zúñiga, G. (1991). Moluscos de la Laguna Tampamachoco, Veracruz, México: sistemática y ecología. Anales del Instituto de Ciencias del Mar y Limnología UNAM, 18, 289-328.

Sangiorgio, F., Quintino, V., Rosati, I., Rodrigues, A. M., Pinna, M., \& Basset, A. (2014). Macrofauna in Mediterranean and Black Sea transitional aquatic ecosystems: A comparative study of the benthic populations sampled by box corer and leaf bags. Ecological Indicators, 38, 159-169.

Savage, V. M., Gillooly, J. F., Woodruff, W. H., West, G. B., Allen, A. P., Enquist, B. J., \& Brown, J. H. (2004). The predominance of quarter-power scaling in biology. Functional Ecology, 18, 257-282.

Schmid, P. E., Tokeshi, M., \& Schmid-Araya, J. M. (2000). Relation between population density and body size in stream communities. Science, 289, 1557-1560.

Schmid, P. E., Tokeshi, M., \& Schmid-Araya, J. M. (2002). Scaling in stream communities. Proceedings of the Royal Society B, 269, 2587-2594.

Sheldon, R. W., Prakash, A., \& Sutcliffe Jr., W. H. (1972). The size distribution of particles in the ocean. Limnology and Oceanography, 17, 327-340. 
Siemann, E., Tilman, D., \& Haarstad, J. (1996). Insect species diversity, abundance and body size relationships. Nature, 380, 704-706.

Sola, J. C. (1996). Population dynamics, reproduction, growth, and secondary production of the mud-snail Hydrobia ulvae (Pennant). Journal of Experimental Marine Biology and Ecology, 205, 49-62.

Viegas, I., Martinho, F., Neto, J., \& Pardal, M. (2007). Population dynamics, distribution and secondary production of the brown shrimp Crangon crangon (L.) in a southern European estuary: latitudinal variations. Scientia Marina, 71, 451-460.
West, G. B., Brown, J. H., \& Enquist, B. J. (2000). The origin of universal scaling laws in biology. In J. H. Brown, \& G. B. West (Eds.), Scaling in biology (pp. 87-112). New York: Oxford University Press.

White, E. P., Ernest, S. K., Kerkhoff, A. J., \& Enquist, B. J. (2007). Relationships between body size and abundance in ecology. Trends in Ecology \& Evolution, 22, 323-330.

White, E. P., Enquist, B. J., \& Green, J. L. (2008). On estimating the exponent of power-law frequency distributions. Ecology, 89, 905-912.

Zar, J. H. (2010). Biostatistical analysis. Upper Saddle River: Prentice Hall. 